\title{
ANALISIS PERHITUNGAN HARGA POKOK SEWA KAMAR BERDASARKAN ACTIVITY BASED COSTING SYSTEM PADA HOTEL RANGGONANG SEKAYU
}

\author{
Deswati Supra \\ deswatisupra98@gmail.com \\ Dosen STIE Rahmaniyah Sekayu
}

\begin{abstract}
This study aims to determine the calculation of the room cost using the Activity Based Costing System at the Ranggonang Hotel. The data source used by the writer in this study is secondary data. In this study the writer used qualitative and quantitative analysis techniques. The results showed that the Ranggonang Sekayu Hotel was not suitable to use the ABC method in calculating the cost of room rent. This is because the cost of room rent using the $A B C$ method is greater which will have an impact on the high room rental rates at the Ranggonang Sekayu Hotel.

Keywords: Cost of Goods Sold, Room Rent, Activity Based Costing Method
\end{abstract}

\section{PENDAHULUAN}

\subsection{Latar Belakang Masalah}

Hotel Ranggonang Sekayu merupakan satu-satunya hotel bintang tiga yang ada di Kabupaten Musi Banyuasin yang terletak di Jalan Merdeka Kelurahan Balai Agung Kecamatan Sekayu Kabupaten Musi Banyuasin. Hotel Ranggonang Sekayu merupakan Badan Usaha Milik Daerah (BUMD) yang pengelolaannya dibawah PT Muba Link. Hotel Ranggonang Sekayu menyediakan beberapa fasilitas penunjang dalam kegiatan operasinya seperti karaoke, loundry, restoran dan lainnya yang sifatnya menghasilkan keuntungan.

Tarif sewa kamar Hotel Ranggonang Sekayu dibagi menjadi 2 (dua) tipe tarif yaitu public dan corporate. Tarif sewa kamar tersebut ditentukan oleh manajer Hotel Ranggonang Sekayu berdasarkan pada basic cost of room yang memperhitungkan barang habis pakai ditambah dengan cost room sebesar 35\%, tax and services $21 \%$ dan alokasi pembebanan operasional sehingga diperoleh hasil untuk ditetapkan sebagai tarif sewa kamar bersih untuk corporate dan harga sewa kamar untuk public. Hotel Ranggonang Sekayu dalam menentukan tarif sewa kamar tidak berdasarkan biaya pada kegiatan/aktivitas kemudian pada 
Jurnal Ilmiah Akuntansi Rahmaniyah (JIAR)

Vol. 3 No.2, Juni 2020, $86-102$

Supra

produk sehingga akan menimbulkan banyak masalah karena tarif sewa yang ditetapkan tidak mencerminkan biaya yang sebenarnya diserap untuk menghasilkan produk tersebut. Sebagai akibatnya akan muncul tarif sewa kamar yang under costing atau over costing.

Berdasarkan latar belakang masalah di atas, maka Penulis melakukan penelitian dengan judul Analisis Perhitungan Harga Pokok Sewa Kamar Menggunakan Activity Based Costing System Pada Hotel Ranggonang Sekayu.

\subsection{Perumusan Masalah}

Berdasarkan latar belakang masalah yang telah diuraikan diatas dapat dirumuskan masalah penelitian adalah bagaimana perhitungan harga pokok sewa kamar menggunakan Activity Based Costing System Pada Hotel Ranggonang Sekayu?

\subsection{Tujuan Penelitian}

Tujuan dalam penelitian ini adalah untuk mengetahui perhitungan harga pokok sewa kamar menggunakan Activity Based Costing System Pada Hotel Ranggonang Sekayu.

\section{LANDASAN TEORI}

\subsection{Konsep Tari Kamar Hotel}

\subsubsection{Pengertian Tarif Kamar Hotel}

Trisnantoro (2018:78), menyebutkan tarif adalah nilai suatu jasa pelayanan yang ditetapkan dengan ukuran sejumlah uang berdasarkan pertimbangan bahwa dengan nilai uang tersebut sebuah hotel bersedia memberikan jasa kepada pelanggan.

\subsubsection{Cara-cara Penetapan Tarif Kamar Hotel}

Yoeti (2017:189), menyatakan cara-cara penetapan tarif kamar hotel yang sering digunakan pihak manajemen hotel dalam penetuan tarif, yakni: Target Profit Pricing, Perceived-Value Pricing, Going Rate, Price Ranging, ValueAdded Pricing, dan Price Skimming.

\subsection{Konsep Harga Pokok Penjualan}

\subsubsection{Pengertian Harga Pokok Penjualan}


Menurut Munandar (2017:155), harga pokok penjualan (Cost Of Goods Sold) adalah biaya untuk memproduksi barang yang terjual. Harga Pokok Penjualan (HPP) merupakan salah satu unsur elemen dari laporan laba-rugi suatu perusahaan dagang.

\subsubsection{Manfaat Harga Pokok Penjualan}

Menurut Carter dan Usry (2017:122), ada 2 (dua) manfaat dari harga pokok penjualan yaitu:

1. Sebagai patokan untuk menentukan harga jual.

2. Untuk mengetahui laba yang diinginkan perusahaan. Apabila harga jual lebih besar dari harga pokok penjualan maka akan diperoleh laba, dan sebaliknya apabila harga jual lebih rendah dari harga pokok penjualan akan diperoleh kerugian.

Menurut Carter dan Usry (2017:122), unsur-unsur yang membentuk harga pokok penjualan antara lain: persediaan awal barang dagang, persediaan akhir barang dagang, dan pembelian bersih.

\subsection{Konsep Harga Jual Kamar Hotel}

\subsubsection{Dasar Harga Jual Kamar Hotel}

Menurut Gitosudarmo (2016:223), terdapat 3 (tiga) hal yang menjadi dasar dalam menentukan harga jual pada perusahaan perhotelan yaitu : dasar biaya, dasar konsumen, dan dasar persaingan. Terdapat strategi penyesuaian yang dapat digunakan oleh hotel dalam menentukan harga agar dapat menarik pelanggan, yaitu dengan beberapa cara: potongan harga, diskriminasi harga, dan harga psikologis.

\subsubsection{Tujuan dan Manfaat Pentuan Harga Jual}

Menurut Sugiarto dan Sri (2014:3), tujuan menetapkan harga kamar adalah sebagai berikut:

a. Memperoleh keuntungan yang diharapkan bagi hotel yang bersangkutan.

b. Pengembalian investasi (modal yang ditanamkan) sesuai dengan target waktu yang telah ditetapkan.

c. Memperkecil pola persaingan yang ada.

d. Memperbaiki atau mempertahankan market share (pangsa pasar) yang ada.

e. Meningkatkan penjualan product line (garis hubungan bisnis dan produknya). 
Menurut Mulyadi (2017:348), dalam keadaan normal, harga jual harus mampu menutup biaya penuh dan menghasilkan laba yang sepadan dengan investasi. Dalam keadaan khusus, harga jual produk tidak dibebani tugas untuk menutup seluruh biaya penuh. Setiap harga jual diatas biaya variable telah memberikan kontribusi dalam menutup biaya tetap.

\subsection{Konsep Activity Based Costing}

\subsubsection{Pengertian Activity Based Costing}

Hongren (2018:28), mendefinisikan Activity Based Costing sebagai suatu sistem pendekatan perhitungan biaya yang dilakukan berdasarkan aktivitasaktivitas yang ada di perusahaan. Sistem ini dilakukan dengan dasar pemikiran bahwa penyebab timbulnya biaya adalah aktivitas yang dilakukan dalam suatu perusahaan, sehingga wajar bila pengalokasian biaya-biaya tidak langsung dilakukan berdasarkan aktivitas tersebut.

\subsubsection{Kriteria Penerapan Activity Based Costing System Pada Perusahaan}

Hansen dan Mowen (2015:165), menyebutkan dalam penerapannya, terdapat beberapa kriteria penerapan Activity Based Costing pada perusahaan, antara lain : Product diversity, Support diversity, Common processes, Period cost allocation, Rate of growth of period costs, Pricing freedom, Period expense ratio, Strategic considerations, Cost reduction effort, dan Analysis of frequency

\subsubsection{Klasifikasi Aktivitas}

Hongren (2018:43), menyebutkan sistem ABC membagi aktivitas kedalam

4 (empat) tingkatan, yaitu

1. Aktivitas tingkat unit (Unit-Level Activities)

2. Aktivitas tingkat kelompok unit (Batch-Level Activities)

3. Aktivitas pendukung produk/jasa (Product/Service-Sustaining Activities)

4. Aktivitas pendukung fasilitas (Facility-Sustaining Activities)

\subsubsection{Sistem Activity Based Costing Pada Perusahaan Jasa}

Aktivitas dapat dijumpai baik di perusahaan manufaktur, jasa, dan dagang, serta organisasi sektor publik dan organisasi nirlaba, maka sistem ABC dapat diterapkan sama baiknya di berbagai jenis organisasi tersebut. Hal-hal yang perlu diperhatikan dalam penerapan Activity Based Costing pada perusahaan jasa adalah: identifying and costing activities, special challenger, dan output diversity. 


\subsection{Kerangka Pemikiran}

Kerangka pemikiran dalam penelitian ini disajikan pada Gambar 2.1 sebagai berikut:

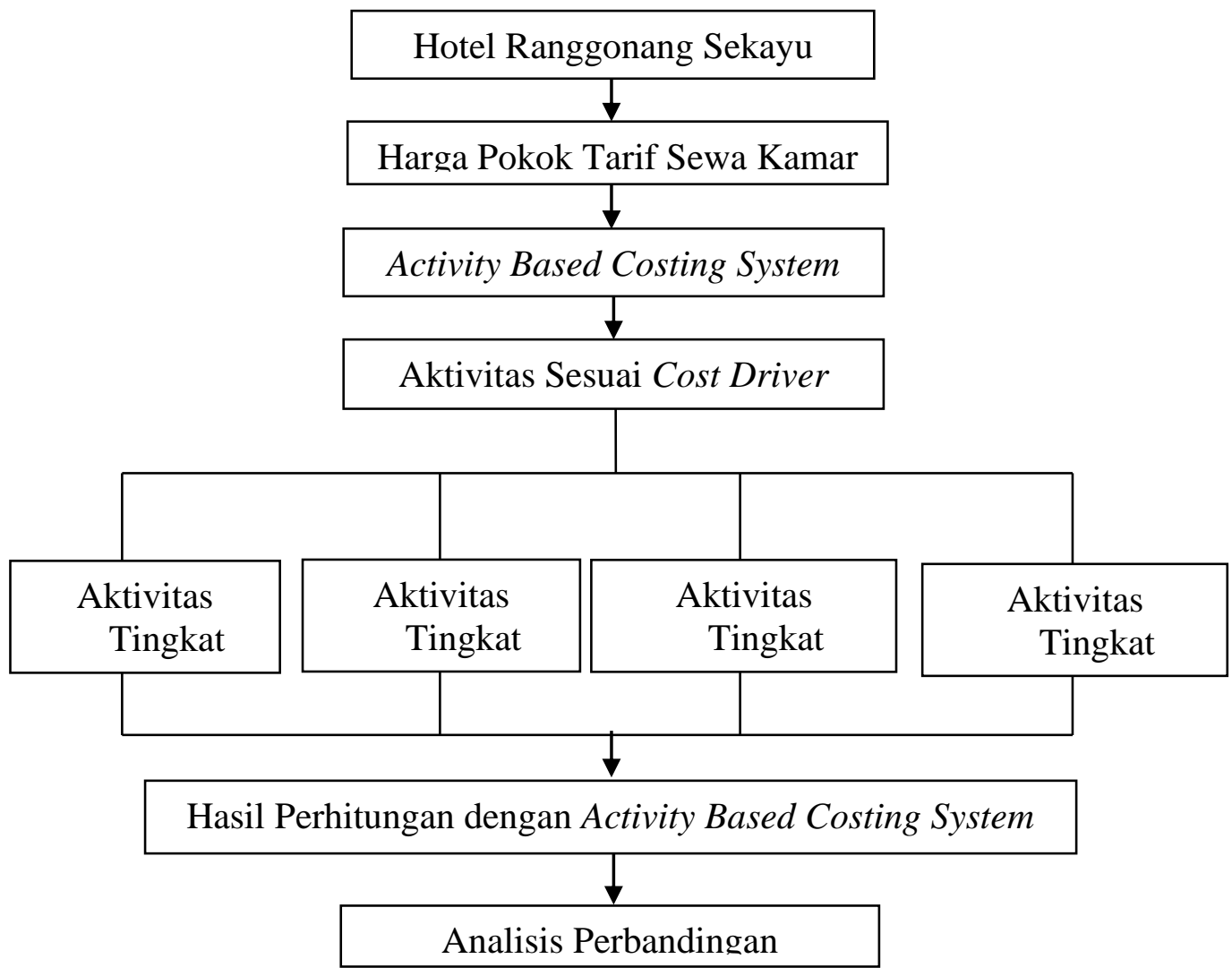

Gambar 2.1

Kerangka Pemikiran

\section{METODOLOGI PENELITIAN}

\subsection{Lokasi dan Waktu Penelitian}

Lokasi penelitian dilakukan pada Wisma Ranggonang Sekayu yang beralamat di Jalan Merdeka Kelurahan Balai Agung Kecamatan Sekayu Kabupaten Musi Banyuasin. Penelitian ini dilakukan selama 2 (dua) bulan.

\subsection{Sumber Data Penelitian}

Husein (2011:45), mengemukakan bahwa sumber data penelitian terdiri dari data primer dan data sekunder. Sumber data yang digunakan Penulis pada 
Jurnal Ilmiah Akuntansi Rahmaniyah (JIAR)

Vol. 3 No.2, Juni 2020, $86-102$

Supra

penelitian ini adalah data sekunder. Data sekunder yang digunakan adalah berupa data tentang laporan harga pokok sewa kamar Tahun 2019 serta gambaran umum Hotel Ranggonang Sekayu.

\subsection{Teknik Pengumpulan Data}

Sugiyono (2012:132), mengemukakan bahwa teknik pengumpulan data terdiri dari:

a. Studi pustaka

b. Penelitian lapangan

1) Wawancara

2) Dokumentasi

Adapun teknik pengumpulan data yang digunakan Penulis adalah :

1. Dokumentasi

Pada penelitian ini Penulis mendokumentasikan data-data tentang laporan harga pokok kamar Tahun 2019 serta gambaran umum Hotel Ranggonang Sekayu.

2. Wawancara

Pada penelitian ini Penulis melakukan wawancara tidak terstruktur atau tidak menggunakan pedoman teks wawancara. Penulis melakukan wawancara mengenai perhtiungan harga pokok sewa kamar Tahun 2019.

3. Studi pustaka

Pada penelitian ini Penulis menelaah teori-teori yang bersumber dan bukubuku teks dan jurnal.

\subsection{Teknik Analisis Data}

Sugiyono (2012:131), juga mengemukakan bahwa teknik analisis data terdiri dari:

1. Teknik analisis kuantitatif

2. Teknik analisis kualitatif

Pada penelitian ini peneliti menggunakan teknik analisis kualitatif dan kuantitatif. Langkah-langkah analisis dalam penelitian ini antara lain :

1. Mencantumkan harga pokok atau harga jual tarif kamar hotel pada Hotel Ranggonang Sekayu. 
2. Melakukan perhitungan harga pokok tarif kamar hotel menggunakan metode Activity Based Costing System, perhitungan harga pokok produknya terdiri dari biaya overhead yang dialokasikan dengan menggunakan dua cost driver yakni lama hari tamu menginap dan jumlah tamu yang menginap, dilakukan dengan cara berikut :

a. Mengidentifikasi biaya dan aktivitas yang terjadi. Untuk mengidentifikasi biaya pada berbagai aktivitas, pihak hotel perlu mengelompokkan seluruh aktivitas menurut cara bagaimana aktivitas tersebut mengkonsumsi sumber daya.

b. Membebankan biaya sumber daya pada aktivitas. Metode Activity Based Costing System menggunakan pemicu biaya untuk membebankan biaya sumber daya dan aktivitas, karena aktivitas memicu timbulnya biaya dari sumber daya yang digunakan dalam operasional perusahaan.

c. Membebankan biaya aktivitas pada produk atau jasa. Pembebanan biaya aktivitas pada produk atau jasa dilakukan melalui dua langkah, yaitu menghitung tarif tiap kelompok aktivitas dan pembebanan biaya pada produk atau jasa.

d. Menentukan tarif per unit cost driver.

e. Membebankan biaya ke produk atau jasa dengan menggunakan tarif cost driver dan ukuran aktivitas.

3. Melakukan perbandingan perhitungan harga pokok tarif kamar hotel yang saat ini digunakan oleh Hotel Ranggonang Sekayu dengan menggunakan metode Activity Based Costing System.

4. Menarik kesimpulan dari perbandingan perhitungan yang terjadi.

\section{HASIL DAN PEMBAHASAN}

Berikut ini disajikan hasil analisis perhitungan harga pokok kamar menggunakan Activity Based Costing System pada Hotel Ranggonang Sekayu.

\subsection{Analisis Perhitungan Harga Pokok Kamar Pada Hotel Ranggonang Sekayu}

Berikut ini data tentang perhitungan harga pokok sewa kamar Hotel Ranggonang Sekayu yang disajikan pada Tabel 4.1: 
Tabel 4.1

Hotel Ranggonang Sekayu

Perhitungan Harga Pokok Sewa Kamar

Tahun 2019

\begin{tabular}{|c|c|c|c|c|c|c|c|c|c|c|c|c|c|c|}
\hline \multirow[b]{2}{*}{ No. } & \multirow{2}{*}{ Discription } & \multirow{2}{*}{ Unit } & \multicolumn{3}{|c|}{ Suite } & \multicolumn{3}{|c|}{ Junior Suite } & \multicolumn{3}{|c|}{ Deluxe } & \multicolumn{3}{|c|}{ Superior } \\
\hline & & & Qty & Price & Value & qty & Price & value & qty & Price & value & qty & Price & value \\
\hline 1 & Aqua $330 \mathrm{ml}$ & Btl & 2 & 1.042 & 2.084 & 2 & 1.042 & 2.084 & 2 & 1.042 & 2.084 & 2 & 1.042 & 2.084 \\
\hline 2 & Tissue box & Ktk & 1 & 3.500 & 3.500 & 1 & 3.500 & 3.500 & 1 & 3.500 & 3.500 & 1 & 3.500 & 3.500 \\
\hline 3 & Map Logo & Lbr & 1 & 4.500 & 4.500 & 1 & 4.500 & 4.500 & & & & & & \\
\hline 4 & Kertas Logo & & & & & & & & & & & 1 & 280 & 280 \\
\hline 5 & Sabun & Pcs & 2 & 1.000 & 2.000 & 2 & 1.000 & 2.000 & 1 & 1.000 & 1.000 & 1 & 1.000 & 1.000 \\
\hline 6 & Bathfoam & Pcs & 1 & 1.125 & 1.125 & 1 & 1.125 & 1.125 & 1 & 1.125 & 1.125 & & & \\
\hline 7 & Samphoo & Pcs & 1 & 1.125 & 1.125 & 1 & 1.125 & 1.125 & 1 & 1.125 & 1.125 & 1 & 1.125 & 1.125 \\
\hline 8 & Dental Kit & Pcs & 2 & 1.350 & 2.700 & 2 & 1.350 & 2.700 & 1 & 1.350 & 1.350 & 1 & 1.350 & 1.350 \\
\hline 9 & Shower cup & Pcs & 1 & 850 & 850 & 1 & 850 & 850 & 1 & 850 & 850 & 1 & 850 & 850 \\
\hline 10 & Rabish Bag & Pcs & 1 & 1.300 & 1.300 & 1 & 1.300 & 1.300 & 1 & 1.300 & 1.300 & 1 & 1.300 & 1.300 \\
\hline 11 & Tissue Roll & Roll & 1 & 1.875 & 1.875 & 1 & 1.875 & 1.875 & 1 & 1.875 & 1.875 & 1 & 1.875 & 1.875 \\
\hline 12 & Hanger & Pcs & 5 & 3.000 & 15.000 & 5 & 3.000 & 15.000 & 5 & 3.000 & 15.000 & 5 & 3.000 & 15.000 \\
\hline 13 & Laundry Bag & Lbr & 2 & 835 & 1.670 & 2 & 835 & 1.670 & 2 & 835 & 1.670 & 2 & 835 & 1.670 \\
\hline 14 & Laundry Bill & Lbr & 1 & 740 & 740 & 1 & 740 & 740 & 1 & 740 & 740 & 1 & 740 & 740 \\
\hline 15 & Glass Bag & Pcs & 2 & 300 & 600 & 2 & 300 & 600 & 2 & 300 & 600 & 2 & 300 & 600 \\
\hline 16 & Glass Coaster & Pcs & 1 & 600 & 600 & 1 & 600 & 600 & & & & & & \\
\hline 17 & Slipper / sandal & $\mathrm{Bh}$ & 2 & 3.500 & 7.000 & 2 & 3.500 & 7.000 & 1 & 3.500 & 3.500 & 1 & 3.500 & 3.500 \\
\hline 18 & Pencil & Btg & 1 & 950 & 950 & 1 & 950 & 950 & 1 & 950 & 950 & 1 & 950 & 950 \\
\hline 19 & Nescafe Sachet & achet & 2 & 500 & 1.000 & 2 & 500 & 1.000 & 2 & 500 & 1.000 & 2 & 500 & 1.000 \\
\hline 20 & Gula Sachet & achet & 2 & 300 & 600 & 2 & 300 & 600 & 2 & 500 & 1.000 & 2 & 300 & 600 \\
\hline 21 & Tea Sachet & achet & 2 & 500 & 1.000 & 2 & 500 & 1.000 & 2 & 500 & 1.000 & 2 & 500 & 1.000 \\
\hline 22 & Creamer & achet & 2 & 300 & 600 & 2 & 300 & 600 & & & & & & \\
\hline No. & Discription & Unit & & Suite & & & unior $\mathrm{S}$ & & & Deluxe & & & Super & \\
\hline
\end{tabular}




\begin{tabular}{|c|c|c|c|c|c|c|c|c|c|c|c|c|c|c|}
\hline & & & Qty & Price & Value & qty & Price & value & qty & Price & value & qty & Price & Value \\
\hline 23 & Pulpy Orange & Btl & 2 & 6.000 & 12.000 & 1 & 6.000 & 6.000 & & & & & & \\
\hline 24 & Oxy Mineral Water & Btl & 2 & 8.000 & 16.000 & 1 & 8.000 & 8.000 & & & & & & \\
\hline 25 & Teh Botol & Btl & 2 & 7.000 & 14.000 & 1 & 7.000 & 7.000 & & & & & & \\
\hline 26 & Kranting Daeng & Btl & 1 & 5.000 & 5.000 & 1 & 5.000 & 5.000 & & & & & & \\
\hline 27 & Silverqueen Jumbo & Btg & 3 & 13.000 & 39.000 & 1 & 13.000 & 13.000 & & & & & & \\
\hline 28 & Pocari Sweet & Btl & 2 & 6.000 & 12.000 & 1 & 6.000 & 6.000 & & & & & & \\
\hline 29 & Biaya Listrik & & 1 & 50.000 & 50.000 & 1 & 50.000 & 50.000 & 1 & 50.000 & 50.000 & 1 & 50.000 & 50.000 \\
\hline 30 & Biaya Air & & 1 & 20.000 & 20.000 & 1 & 20.000 & 20.000 & 1 & 20.000 & 20.000 & 1 & 20.000 & 20.000 \\
\hline 31 & Pencucian Bed Cover & Lbr & 1 & 20.000 & 20.000 & 1 & 20.000 & 20.000 & 1 & 20.000 & 20.000 & 1 & 20.000 & 20.000 \\
\hline 32 & Pencucian Blanket & Lbr & 1 & 20.000 & 20.000 & 1 & 20.000 & 20.000 & 1 & 20.000 & 20.000 & 1 & 20.000 & 20.000 \\
\hline 33 & Pencucian Pillow Case & Lbr & 2 & 5.000 & 10.000 & 2 & 5.000 & 10.000 & 2 & 5.000 & 10.000 & 2 & 5.000 & 10.000 \\
\hline 34 & Pencucian Bath Towel & Lbr & 2 & 12.500 & 25.000 & 2 & 12.500 & 25.000 & 2 & 12.500 & 25.000 & 2 & 12.500 & 25.000 \\
\hline 35 & Pencucian Bath Math & Lbr & 1 & 7.500 & 7.500 & 1 & 7.500 & 7.500 & 1 & 7.500 & 7.500 & 1 & 7.500 & 7.500 \\
\hline 36 & Pencucian Sheet & Lbr & 2 & 15.000 & 30.000 & 2 & 15.000 & 30.000 & 2 & 15.000 & 30.000 & 2 & 15.000 & 30.000 \\
\hline 37 & Breakfast 2 orang / kamar & $\mathrm{Kmr}$ & 2 & 5.000 & 10.000 & 2 & 5.000 & 10.000 & 2 & 5.000 & 10.000 & 2 & 5.000 & 10.000 \\
\hline \multicolumn{3}{|c|}{ Biaya Fasilitas kamar } & & & 341.319 & & & 288.319 & & & 232.169 & & & 230.924 \\
\hline
\end{tabular}

Sumber: Hotel Ranggonang Sekayu, Tahun 2020, data diolah 
Berdasarkan Tabel 4.1, dapat dijelaskan bahwa Hotel Ranggonang Sekayu melakukan perhitungan harga pokok penjualan hanya berdasarkan biaya cost room. Harga pokok penjualan kamar tipe suite sebesar Rp. 288.319, harga pokok penjualan kamar tipe deluxe pada Hotel Ranggonang Sekayu sebesar Rp. 232.169 dan harga pokok penjualan kamar tipe superior pada Hotel Ranggonang Sekayu sebesar Rp. 230.924.

\subsection{Perhitungan Harga Pokok Kamar Dengan Metode Activity Based Costing System Pada Hotel Ranggonang Sekayu}

Langkah-langkah yang dilakukan dalam menghitung harga pokok kamar dengan menggunakan metode $\mathrm{ABC}$ :

1. Mengidentifikasi biaya dan aktivitas yang terjadi.

Mengidentifikasi biaya yang dikeluarkan perusahaan. Kemudian biaya-biaya tersebut dialokasikan ke tiap jenis kamar mulai dari supperior, deluxe, suite, dan Junior Suite Biaya yang terjadi pada departemen kamar ialah aktivitas layanan kamar.

2. Mengidentifikasi aktivitas biaya berdasarkan level aktivitasnya

Berikut ini adalah data tentang aktivitas biaya tidak lansung dan level aktivitasnya pada Hotel Ranggonang Sekayu yang disajikan pada Tabel 4.2.

Tabel 4.2

Identifikasi Aktivitas dan Level Aktivitas

\begin{tabular}{|c|l|l|}
\hline No & \multicolumn{1}{|c|}{ Aktivitas } & \multicolumn{1}{c|}{ Level Aktivitas } \\
\hline 1 & Aktivitas langganan daya dan jasa & Unit level \\
\hline 2 & Aktivitas pemberian makan pagi & Unit level \\
\hline 3 & Aktivitas listrik & Facility level \\
\hline 4 & Aktivitas air & Facility level \\
\hline 5 & Aktivitas penyusutan & Facility level \\
\hline 6 & Aktivitas pemasaran & Facility level \\
\hline 7 & Aktivitas penggajian & Facility level \\
\hline 8 & Aktivitas pemeliharaan & Facility level \\
\hline
\end{tabular}

3. Mengidentifikasi Cost Driver.

a. Aktivitas langganan daya dan jasa untuk dasar pengalokasian dapat berdasarkan jumlah tamu yang menginap dan jumlah kamar terjual. Tetapi dengan mengingat bahwa biaya-biaya meningkat jika jumlah kamar terjual, maka yang dapat dijadikan cost driver adalah jumlah kamar terjual.

b. Aktivitas pemberian makan pagi ditelusuri secara langsung dengan tarif full breakfast buffet sebesar Rp. 10.000,-/orang. Untuk dasar pengalokasian dapat berdasarkan jumlah tamu yang menginap dan jumlah kamar yang terjual. Tapi peningkatan biaya 
pada pemberian makan pagi tergantung pada jumlah tamu yang menginap, maka yang dijadikan cost driver adalah jumlah tamu yang menginap.

c. Aktivitas listrik untuk dasar pengalokasian berdasarkan jumlah kamar terjual, maka cost driver yang tepat adalah jumlah kamar terjual.

d. Aktivitas air untuk dasar pengalokasian berdasarkan jumlah kamar terjual, maka cost driver yang tepat adalah jumlah kamar terjual.

e. Aktivitas penyusutan untuk dasar pengalokasian dapat berdasarkan jumlah kamar tersedia dan jumlah kamar terjual. Tetapi aktiva tetap dan peralatan hotel yang disusutkan digunakan untuk semua kamar yang ada, maka cost driver yang tepat adalah jumlah kamar tersedia.

f. Aktivitas pemasaran dapat dialokasikan berdasarkan jumlah kamar tersedia dan jumlah kamar terjual. Tetapi karena pemasaran dilakukan dengan tujuan untuk menjual semua kamar yang tersedia, maka cost driver yang tepat adalah jumlah kamar tersedia.

g. Aktivitas penggajian untuk dasar pengalokasian berdasarkan jumlah jam kerja, maka cost driver yang tepat adalah jumlah jam kerja.

h. Aktivitas pemeliharaan meliputi pemeliharaan gedung dan peralatan hotel dapat dialokasikan berdasarkan jumlah kamar tersedia dan jumlah kamar terjual. Tetapi pemeliharaan gedung dan peralatan hotel tidak hanya dilakukan pada kamar yang terjual, maka cost driver yang tepat adalah jumlah kamar tersedia.

Berikut ini disajikan data tentang cost pool dan cost driver pada Tabel 4.3 :

Tabel 4.3

Cost Pool Dan Cost Driver

\begin{tabular}{|l|l|l|}
\hline \multicolumn{1}{|c|}{ Cost Pool } & \multicolumn{1}{c|}{ Keterangan } & \multicolumn{1}{c|}{ Cost Driver } \\
\hline Cost Pool I & Aktivitas langganan daya dan jasa & Jumlah kamar terjual \\
\hline Cost Pool II & Aktivitas pemberian makan pagi & Jumlah tamu menginap \\
\hline Cost Pool III & Aktivitas pemasaran & Jumlah kamar tersedia \\
\hline Cost Pool IV & $\begin{array}{l}\text { Aktivitas pemeliharaan } \\
\text { Aktivitas penyusutan }\end{array}$ & Jumlah luas lantai \\
\hline Cost Pool V & Aktivitas karyawan & Jumlah jam kerja \\
\hline
\end{tabular}

Sumber: Hotel Ranggonang Sekayu, Tahun 2020, data diolah

Berdasarkan uraian di atas, berikut ini disajikan data tentang cost pool I pada Tabel 4.4, cost pool II pada Tabel 4.5, cost pool III pada Tabel 4.6, cost pool IV pada Tabel 4.7 dan cost pool $\mathrm{V}$ pada Tabel 4.8 dibawah ini:

Tabel 4.4 
Jurnal Ilmiah Akuntansi Rahmaniyah (JIAR)

Vol. 3 No.2, Juni 2020, 86 - 102

\begin{tabular}{|l|r|}
\hline \multicolumn{1}{|c|}{ Aktivitas } & \multicolumn{1}{c|}{ Biaya (Rp) } \\
\hline Biaya Langganan Listrik & 211.341 .465 \\
\hline Biaya Langganan Telepon/Fax & 12.205 .510 \\
\hline Biaya Langganan Air & 53.586 .348 \\
\hline Biaya Langganan Koran/Majalah/Televisi & 9.343 .585 \\
\hline Biaya Langganan Bahan Bakar & 23.144 .299 \\
\hline Jumlah & $\mathbf{3 0 9 . 6 2 1 . 2 0 7}$ \\
\hline
\end{tabular}

Sumber: Hotel Ranggonang Sekayu, Tahun 2020, data diolah

Tabel 4.5

Cost Pool II

Aktivitas Pemberian Makan Pagi

\begin{tabular}{|l|r|}
\hline \multicolumn{1}{|c|}{ Aktivitas } & \multicolumn{1}{c|}{ Biaya (Rp) } \\
\hline Full breakfast buffet (Rp. $10.000 \times 8.670$ tamu) & 86.700 .000 \\
\hline Jumlah & $\mathbf{8 6 . 7 0 0 . 0 0 0}$ \\
\hline
\end{tabular}

Sumber: Hotel Ranggonang Sekayu, Tahun 2020, data diolah

Tabel 4.6

Cost Pool III

Aktivitas Pemasaran

\begin{tabular}{|l|r|}
\hline \multicolumn{1}{|c|}{ Aktivitas } & \multicolumn{1}{c|}{ Biaya (Rp) } \\
\hline Biaya Reklame & 1.160 .356 \\
\hline Jumlah & $\mathbf{1 . 1 6 0 . 3 5 6}$ \\
\hline
\end{tabular}

Sumber: Hotel Ranggonang Sekayu, Tahun 2020, data diolah

Tabel 4.7

Cost Pool IV

Aktivitas Pemeliharaan dan Penyusutan

\begin{tabular}{|l|r|}
\hline \multicolumn{1}{|c|}{ Aktivitas } & \multicolumn{1}{c|}{ Biaya (Rp) } \\
\hline Biaya Penyusutan Taman dan Penyempurnaan Tanah & 2.531 .726 \\
\hline Biaya Penyusutan Bangunan dan Gedung & 289.981 .560 \\
\hline Biaya Penyusutan Peralatan dan Mesin & 8.962 .796 \\
\hline Biaya Penyusutan Kendaraan & 1.157 .576 \\
\hline Biaya Penyusutan Inventaris & 316.342 .684 \\
\hline Biaya Pemeliharaan Peralatan dan Mesin & 33.756 .775 \\
\hline Biaya Pemeliharaan Gedung dan Bangunan & 21.538 .202 \\
\hline Biaya Pemeliharaan Sarana Phisik Lainnya & 5.065 .582 \\
\hline Biaya Pemeliharaan Kendaraan & 2.744 .506 \\
\hline Biaya Pemeliharaan Perlengkapan & 30.588 .743 \\
\hline Biaya Kebersihan/Laundry & 28.133 .211 \\
\hline Biaya Pemeliharaan Software & 23.808 .125 \\
\hline Jumlah & $\mathbf{7 6 4 . 6 1 1 . 4 8 6}$ \\
\hline
\end{tabular}

Sumber: Hotel Ranggonang Sekayu, Tahun 2020, data diolah

Tabel 4.8

Cost Pool V

Aktivitas Pegawai 
Jurnal Ilmiah Akuntansi Rahmaniyah (JIAR)

Vol. 3 No.2, Juni 2020, $86-102$

\begin{tabular}{|l|r|}
\hline Biaya Gaji dan Tunjangan & 1.194 .867 .127 \\
\hline Makan Karyawan & 72.726 .741 \\
\hline Seragam Pegawai & 280.624 \\
\hline Uang Pesangon & 7.355 .875 \\
\hline Honorarium Lainnya & 1.122 .498 \\
\hline Biaya Kesehatan Pegawai & 931.673 \\
\hline Biaya BPJS-Kesehatan & 40.682 .884 \\
\hline Biaya BPJS-Ketenagakerjaan & 62.936 .604 \\
\hline Jumlah & $\mathbf{1 . 3 8 0 . 9 0 4 . 0 2 6}$ \\
\hline
\end{tabular}

Supra

Sumber: Hotel Ranggonang Sekayu, Tahun 2020, data diolah

Berdasarkan data tentang cost pool di atas, maka berikut ini disajikan data tentang cost drvier yang digunakan pada Tabel 4.9 di bawah ini:

Tabel 4.9

Pengalokasian Data Cost Driver

\begin{tabular}{|c|l|l|r|}
\hline No & \multicolumn{1}{|c|}{ Alokasi } & \multicolumn{1}{|c|}{ Cost Driver } & Jumlah \\
\hline 1 & Alokasi jumlah kamar terjual & Superior & 4.078 \\
& & Deluxe & 2.457 \\
& & Junior Suite & 155 \\
& & Suite & 132 \\
\hline 2 & Alokasi jumlah tamu & Jumlah & 6.822 \\
& menginap & Superior & 4.752 \\
& & Deluxe & 3.471 \\
& & Junior Suite & 241 \\
& & Suite & 206 \\
\hline 3 & Alokasi jumlah kamar tersedia & Jumlah & 8.670 \\
& & Superior & 4.380 \\
& & Deluxe & 5.840 \\
& & Junior Suite & 730 \\
& & Suite & 730 \\
\hline 4 & Alokasi jumlah luas lantai & Jumlah & 11.680 \\
& & Superior & 420 \\
& & Deluxe & 450 \\
& & Junior Suite & 90 \\
& & Suite & 112 \\
& & Jumlah & 1.072 \\
\hline 5 & Alokasi jumlah jam kerja & Superior & 56.160 \\
& karyawan & Deluxe & 36.144 \\
& & Junior Suite & 1.348 \\
& & Suite & 1.112 \\
& & Jumlah & 94.800 \\
\hline
\end{tabular}

Sumber: Hotel Ranggonang Sekayu, Tahun 2020, data diolah

Berdasarkan Tabel 4.9 di atas, dapat dijelaskan bahwa alokasi jumlah kamar terjual diperoleh dari data rekapitulasi penjulan kamar Hotel Ranggonang Sekayu selama tahun 2019 yang terdiri dari superior sebanyak 4.078 kamar terjual, deluxe 2.457 kamar terjual dan junior suite sebanyak 155 kamar terjual serta kamar suite sebanyak 132. Alokasi jumlah tamu 
Jurnal Ilmiah Akuntansi Rahmaniyah (JIAR)

Vol. 3 No.2, Juni 2020, $86-102$

Supra

menginap diperoleh dari data rekapitulasi jumlah tamu yang menginap pada Hotel Ranggonang Sekayu selama tahun 2019 yang terdiri dari superior sebanyak 4.752 tamu, deluxe 3.471 tamu junior suite 241 dan suite 206 tamu.

Berdasarkan data tentang cost pool dan cost driver di atas, maka berikut ini disajikan data tentang tarif cost pool yang digunakan pada Tabel 4.10 di bawah ini:

Tabel 4.10

Tarif Cost Pool

(Dalam Rupiah)

\begin{tabular}{|l|r|r|r|}
\hline \multicolumn{1}{|c|}{ Cost Pool } & Total Cost Pool & Cost Driver & \multicolumn{1}{c|}{ Tarif Cost Pool } \\
\hline Cost Pool I & 309.621 .207 & 6.822 & 45.386 \\
\hline Cost Pool II & 86.700 .000 & 8.670 & 10.000 \\
\hline Cost Pool III & 1.160 .356 & 11.680 & 99 \\
\hline Cost Pool IV & 764.611 .486 & 1.072 & 713.256 \\
\hline Cost Pool V & 1.380 .904 .026 & 94.800 & 14.566 \\
\hline
\end{tabular}

Sumber: Hotel Ranggonang Sekayu, Tahun 2020, data diolah

Berdasarkan hasil perhitungan tarif cost pool diatas, berikut ini disajikan biaya yang melekat pada aktivitas dibebankan ke kamar berdasarkan konsumsi atau muatan aktivitas, dapat dilihat pada tabel di bawah ini : 
Tabel 4.11

Hotel Ranggonang Sekayu

Harga Pokok Sewa Kamar

Berdasarkan Metode Activity Based Costing Tahun 2019

(Dalam Rupiah)

\begin{tabular}{|c|c|c|c|c|c|c|c|c|c|c|}
\hline \multirow{2}{*}{ No } & \multirow{2}{*}{ Cost Pool } & $\begin{array}{c}\text { Tarif } \\
\text { Cost } \\
\text { Pool }\end{array}$ & Supperior & Deluxe & $\begin{array}{c}\text { Junior } \\
\text { Suite }\end{array}$ & Suite & Supperior & Deluxe & Junior Suite & Suite \\
\hline 1 & Cost Pool I & 45.386 & 4.078 & 2.457 & 155 & 132 & 185.084 .108 & 111.513 .402 & 7.034 .830 & 5.990 .952 \\
\hline 2 & Cost Pool II & 10.000 & 4.752 & 3.471 & 241 & 206 & 47.520 .000 & 34.710 .000 & 2.410 .000 & 2.060 .000 \\
\hline 3 & Cost Pool III & 99 & 4.380 & 5.840 & 730 & 730 & 433.620 & 578.160 & 72.270 & 72.270 \\
\hline 4 & Cost Pool IV & 713.256 & 420 & 450 & 90 & 112 & 299.567 .520 & 320.965 .200 & 64.193 .040 & 79.884 .672 \\
\hline 5 & Cost Pool V & 14.566 & 56.160 & 36.144 & 1.348 & 1.112 & 818.026 .560 & 526.473 .504 & 19.634 .968 & 16.197 .392 \\
\hline \multicolumn{3}{|c|}{ Total } & & & & 1.350 .631 .808 & 994.240 .266 & 93.345 .108 & 104.205 .286 \\
\hline \multicolumn{3}{|c|}{ Jumlah kamar terjual } & & & & 4.078 & 2.457 & 155 & 132 \\
\hline \multicolumn{3}{|c|}{ Harga pokok sewa kamar } & & & & 331.200 & 404.656 & 602.227 & 789.434 \\
\hline
\end{tabular}

Sumber: Hotel Ranggonang Sekayu, Tahun 2020, data diolah 
Berdasarkan Tabel 4.11 di atas, maka dapat dijelaskan bahwa harga pokok sewa kamar Hotel Ranggonang Sekayu berdasarkan metode Activity Based Costing untuk tipe kamar superior sebesar Rp. 331.200, tipe deluxe sebesar Rp. 404.656 dan tipe junior suite sebesar Rp. 602.227 serta tipe kamar suite sebesar Rp. 789.434. Hal ini menunjukkan perbedaan yang signifikan dengan harga pokok yang dihitung oleh pihak manajemen Hotel Ranggonang Sekayu. Perbedaan hasil perhitungan harga pokok konvensional dan hasil perhitungan harga pokok Activity Based Costing System. Perbedaan tersebut dapat dilihat pada tabel di bawah ini :

Tabel 4.12

Perbandingan Harga Pokok Kamar Hotel Ranggonang Sekayu dan Metode Activity Based Costing

\begin{tabular}{|l|c|c|c|}
\hline Jenis Kamar & $\begin{array}{c}\text { Hotel Ranggonang } \\
\text { Sekayu }\end{array}$ & $\begin{array}{c}\text { Metode Activity } \\
\text { Based Costing }\end{array}$ & Selisih \\
\hline Superior & 230.924 & 331.200 & 100.276 \\
\hline Deluxe & 232.169 & 404.656 & 172.487 \\
\hline Junior Suite & 288.319 & 602.227 & 313.908 \\
\hline Suite & 341.319 & 789.434 & 448.115 \\
\hline
\end{tabular}

Sumber: Hotel Ranggonang Sekayu, Tahun 2020, data diolah

Dari tabel 4.12 di atas, dapat dijelaskan bahwa terdapat selisih harga pokok kamar yang telah ditentukan manajemen Hotel Ranggonang Sekayu dengan hasil perhitungan menggunakan pendekatan Activity Based Costing.

\section{SIMPULAN DAN SARAN}

\subsection{Kesimpulan}

Berdasarkan hasil penelitian dan pembahasan, maka dapat disimpulkan bahwa hasil perhitungan harga pokok sewa kamar antara Hotel Ranggonang Sekayu dan metode $\mathrm{ABC}$ menunjukkan terjadi selisih. Metode $\mathrm{ABC}$ pada kamar superior, deluxe, junior suite dan suite, memberikan hasil perhitungan yang lebih besar dari pada harga pokok kamar yang telah ditentukan oleh pihak manajemen hotel.

\subsection{Saran}

Berdasarkan simpuran di atas, maka Penulis memberikan saran diharapkan kedepannya dapat menerapkan Activity Based Costing dalam perhitungan harga pokok sewa kamar, karena akan menghasilkan harga pokok sewa yang akurat namun faktor lain diluar ini tetap harus dipertimbangkan, sehingga harga sewa kamar yang ditetapkan 
dapat memenuhi keinginan masyarakat untuk menginap pada Hotel Ranggonang Sekayu.

\section{DAFTAR PUSTAKA}

Carter, William K. 2017. Akuntansi Biaya. Terjemahan Krista. Jakarta: Salemba Empat

Gitosudarmo, Indriyo. 2016. Manajemen Pemasaran. Yogyakarta: BPFE

Hansen, Don R, dan Maryanne M. Mowen. 2015. Akuntansi Manajemen. Jakarta : Erlangga.

Hongren, Charles T, Datar, Srikant M., dan Foster, George, 2018, Akuntansi Biaya; Penekanan Manajerial, jilid 1, edisi kesebelas, Indeks.

Husein, Umar. 2011. Metode Penelitian Untuk Skripsi dan Tesis Bisnis. Jakarta: PT. Raja Grafindo Persada.

Mulyadi. 2017. Akuntansi Biaya. Yogyakarta: UPP STIM YKPN.

Munandar. 2017. Akuntansi Biaya. Yogyakarta: BPFE

Sugiarto, Endar dan Sri Sulartiningrum. 2014. Pengantar Akomodasi dan Rstaurant. Jakarta: PT Gramedia

Sugiyono. 2012. MetodePenelitian Kuantitatif Kualitatif dan R\&D.Bandung: Alfabeta

Trisnantoro, Laksono. 2018. Memahami Penggunaan Ilmu Ekonomi Dalam Manajemen Rumah Sakit. Yogyakarta: Universitas Gajah Mada

Yoeti, Oka A. 2017. Pengantar Ilmu Pariwisata. Bandung: Angkasa. 